\title{
Chapter 10 \\ Cities Breaking the Mould? Municipal \\ Inclusion of Irregular Migrants in Europe
}

\author{
Sarah Spencer
}

\subsection{Introduction}

Throughout this book we are exploring the conceptual challenges posed by the presence of irregular migrants in Europe and evolving policy responses from the international to the local level. This chapter focuses on municipal responses to irregular migrants and in particular the significance of inclusive responses to restrictive national welfare provisions. The chapter questions whether inclusive responses run counter to national immigration control objectives or whether they may, counterintuitively, contribute to them. It further considers the implications of local responses for national social and economic policy goals.

Management of irregular migration regularly includes legal restrictions on access to welfare services as a means to deter irregular arrival and stay. While there is a variable geography of permitted access and restrictions, the norm is one of exclusion. Thus irregular migrants are regularly denied access by law from services such as shelter, primary and secondary health care, pre- and post-school education and welfare support (FRA 2011; Spencer and Hughes 2015b; Delvino 2017).

At the local level, while some cities and smaller municipalities are notably resistant to any further inclusion of these residents within welfare provision (Ambrosini 2018), others have responded with provision of a wider range of services than national policy requires or in some cases allows. As sub-state tiers of government have pushed the boundaries and insisted on the right to provide the services they consider necessary, there have been tensions with national governments-a collision course that has led to litigation in a number of countries and the near fall of the Dutch coalition government in 2015 (Spencer 2018; Oomen and Baumgärtel 2018).

Some of Europe's larger cities are now seeking recognition for the front-line role they play in managing the presence of irregular migrants and a voice at the policy-

\footnotetext{
S. Spencer $(\square)$

Centre on Migration, Policy and Society, University of Oxford, Oxford, UK

e-mail: sarah.spencer@compas.ox.ac.uk 
making table, using their umbrella bodies to voice that demand. That call has been heard and has secured some international recognition. That support may however not be welcome to those national governments in dispute with sub-state tiers on the extent to which they are inclusive of irregular migrants; migrants who are the potential subjects of enforcement action and removal. Yet there is some evidence that suggests that, far from running counter to national immigration control objectives, local provision to irregular migrants can contribute to them. This chapter explores that apparent contradiction. It asks whether we are indeed witnessing fragmented policy outcomes in the divergence between national and local approaches on welfare provision to this section of the migrant population (Burchianti 2016) or whether these apparently divergent approaches are in fact more coherent than the tensions between them suggest.

\subsection{Context for Municipal Service Provision to Irregular Migrants}

While the most recent, officially accepted, estimate of the number of migrants with irregular status may be considered low, up to just $0.8 \%$ of the population of the thenEU27 (Clandestino 2009; European Commission 2010) migrants are concentrated in urban areas and those with irregular status are no exception (Gebhardt 2010; GLA Economics 2009), not least because it is easier to avoid detection and to earn a living in large cities with significant informal economies (Genç 2018: 2). The Clandestino estimate is from a decade ago and precedes recent arrivals from the 'refugee crisis.' With more than one million people expected to be told to leave once their asylum claim has been processed, but an overall return rate in the EU of less than $50 \%$, many who are refused permission to stay will nevertheless remain (European Commission 2017; EMN 2016). The impact on and policy response from the cities and smaller municipalities in which they live, and the significance of those responses for migration control objectives, are thus important research and policy questions.

National governments have primary responsibility for immigration control, determining policy and taking the lead on implementation while delegating certain tasks to regional and local authorities. National governments also lead on economic and social policies, setting objectives and legal frameworks for access to services, but here regional and local authorities have greater delegated powers and direct responsibility for service delivery. There is thus an overlapping responsibility for policy fields ranging from economic development and public health to social cohesion, education, policing, shelter and social care that impact upon, and are impacted by, the migrant population. Thus, while national governments have lead responsibility for policies on irregular migration, there is a shared responsibility with sub-state tiers for policies on irregular migrants, albeit one in which there is a clear hierarchy in the governance structure. 
Municipalities across Europe have differing mandates, ranging from cities that are also federal states, such as Berlin and Vienna, to small authorities with a more limited remit (CEMR 2011). Cities also enjoy differing levels of autonomy from national governments (European Commission 2015a) so that their scope for policy responses that differ from national approaches vary. Cities in north-west Europe have been found to be subject to firmer policy compliance on migration matters than those in southern Europe where cities have greater scope for policy divergence (Penninx et al. 2014).

\subsection{Municipal Provision}

A shift in the balance of responsibility on migration-related issues in recent years to sub-state tiers, and of the economic and social policies impacted by migration, has widened the scope for policy divergence at the local level. Neoliberalism has decentred the state. The resulting scope for action at sub-state level has led in some areas to nativist responses that reinforce or can exceed the level of exclusion intended by national policymakers (Guiraudon and Lahav 2000; Varsanyi 2011; Ambrosini 2018). In relation to irregular migrants in particular, municipalities may adopt a 'security frame' in which their priority is restrictive measures and reassuring their public that these are in place (Caponio 2014: 5). Inclusion may nevertheless be fostered by intermediaries including civil society organisations, co-ethnics, and municipal street bureaucrats, but here the latter are exercising their discretion in ways that run counter to the official policy of the local authority for which they work (Van der Leun 2006.; Ambrosini 2018).

Scholars have also documented the ways in which a level of municipal autonomy has facilitated an inclusive 'local turn' in policies towards migrants (Caponio and Borkert 2010), municipalities taking advantage of the devolution of responsibilities to overcome some of the constraints in national policy measures. They have become increasingly entrepreneurial in developing their own distinct approaches, moving away from historically-rooted national integration models. As a consequence, local policies can diverge not only from national policy but from that of other municipalities within the same country (Scholten and Penninx 2016; De Graauw and Vermeulen 2016).

In relation to irregular migrants, municipalities are confronted daily with the consequences of irregular status when individuals cannot access the ordinary services of everyday life. They face the challenge of managing the individual, social and economic impacts of migrants' exclusion from work and welfare provisionsexclusion affecting not only the individuals concerned but the wellbeing of other local residents (Wilmes 2011; Spencer and Delvino 2019). As a result, there are municipalities that adopt an inclusive approach towards irregular migrants or do so in relation to one or more services.

Inclusive provision can still be overtly in line with national policy, for instance where education law requires schooling to be inclusive of all children of school age, 
or the law permits the issuing of birth certificates regardless of status. However, municipalities also provide services or civic documentation that go beyond what national policy requires, stretching the limits of local authorities' competences (Genç 2018: 10; Spencer 2018). Services variously provided to irregular migrants include accommodation, food banks, healthcare, legal advice and representation, preschool and school education, apprenticeships, language tuition and skills training, outreach services to street prostitutes, safe reporting of crime for victims and witnesses, subsistence support, and assistance in return to the migrant's country of origin. Services are provided by the authority itself or through collaboration with other public and non-profit organisations that become partners in policy making and implementation in this field (Burchianti 2016; Delvino 2017).

\subsubsection{Tensions in Multi-level Governance}

Inclusive local responses, driven by local factors to address municipal policy objectives (Scholten 2013) in the case of irregular migrants have largely been considered by scholars to run counter to national immigration and welfare policies. Their inclusive intent contrasts with the restrictive and exclusive policies favoured at the national level and "constitute a serious challenge to the established centralist approach to irregular migration management" (Genç 2018: 10).

That interpretation is supported by the tensions that have arisen in the multi-level governance of this issue. As municipal policy responses towards irregular migrants have diverged from national legal and policy frameworks, national governments have (as in relation to municipal integration policies for legal migrants, Scholten 2013: 234), attempted to limit local policy choices but faced claims from local tiers for autonomy to address the issue in the way they deem necessary (Spencer 2018). The resulting tensions have led to political disputes, to instances of non-compliance by the lower tier, and at times to litigation in the courts. Dutch cities, for instance, successfully challenged the exclusion of young people from apprenticeships in 2012 (winning the argument that apprenticeships are 'education' not 'work') and in the courts resisted the government's opposition to their 'Bed, Bath and Bread' provision - a litigious dispute that has only recently been resolved (Spencer 2018; Rosenberger and Koppes 2018). Similar conflicts have been seen at the regional level. Some German Länder refused to provide the Federal immigration authorities with data on pupils with irregular status, contributing to the pressure for that requirement to be withdrawn (Laubenthal 2011). When Italian regions used their legislative powers to extend irregular migrants' entitlements to healthcare, they were challenged by the national government but their right to do so was supported by the Constitutional Court (Delvino and Spencer 2014).

This conflict, where one part of the state is in open dispute with another, is an instance of 'de-coupling' in multi-level governance in the migration field. De-coupling occurs where there is a level of shared responsibility for an issue but a lack of shared framing of the problem (Schön and Rein 1994) and hence of proposed 
solutions if there are no effective means through which differences can be resolved (Scholten 2013). Such tensions come at a cost to municipalities and there is evidence that some seek to avoid conflict by choosing a means of low-visibility provision; whether by funding NGOs to provide a service at arm's length, avoiding asking service users for evidence of immigration status, bending rules that require them to report service users to the immigration authorities, or having no paper trail relating to the beneficiaries of the service (Wilmes 2011: 128; Spencer 2018).

Those tensions, and the steps some authorities take to avoid them, suggest that the local authorities and governments concerned do themselves consider that the inclusion of irregular migrants in these services at the local level runs counter to national policy objectives. Yet there is reason to think that may not, or not always, be the case. In the next section I draw on relevant areas of the migration literature to consider whether, despite policy divergence, municipal responses may nevertheless contribute at least in part to national policy goals.

\subsection{Limits of Enforcement}

It is first of all helpful to recognise that irregular migration and the local presence of migrants with irregular status is a structural phenomenon not a temporary problem that can be addressed through enforcement alone. Rather, it is temporarily "'repaired" by state organisations oscillating between means of repression, silent toleration and resigned acceptance" (Bommes and Sciortino 2011: 17). Demographic pressures, global economic disparities, segmented and informal labour markets, sectoral demand for cheap labour and geo-political conflicts are among the causes of irregular migration and of legal migrants choosing to remain without authorisation (Koser 2010). Scholars have exposed the contradictions in enforcement policies that criminalise irregular migrants while tolerating exploitative labour market policies (as in London); and suggested that this need for workers is effectively acknowledged in the tolerance by national governments of their presence (Chauvin and GarcésMascareñas 2014; Ambrosini 2018: 19).

Thus, while enforcement is regularly considered a priority at the national level and identified in comparative research as an area of national policy convergence, it is not notably effective, leading to pressure for ever more restrictive policies (Koser 2010; Hollifield et al. 2014: 4). Many factors are cited as contributing to the widening gap between enforcement goals and outcomes in industrialised receiving states including employer demand for workers regardless of legal status; the huge costs of implementing more effective policies; a lack of cooperation by sending and transit countries, and liberal domestic human rights norms that constrain the extent to which punitive measures can be used (Guiraudon and Lahav 2000; Hollifield et al. 2014: 4; EMN 2016; Andersson 2016; Ambrosini 2018: 35). Enforcement measures can also prove counterproductive, leading irregular migrants to shift from formal to informal work, from legitimate to criminal behaviour, and from being identifiable to unidentifiable (Engberson and Broeders 2011). The consequence is the continuing 
presence of irregular migrants in Europe and their residence within local communities. As Genç argues, "The persistence of irregular migration shows that despite all the efforts at national, international and regional levels, this type of human mobility cannot be managed as previously conceived by national governments. It demands efforts that transcend mere 'control' and 'prevention'” (2018: 1).

\subsection{Competing Policy Imperatives}

Governments have responded to the enforcement gap by using restrictions on welfare provision to enhance immigration control, aiming to remove any incentive to migrate without authorisation or to remain once a temporary right to stay has expired (Bommes and Geddes 2000). Welfare restrictions, however, have negative consequences that impact on other government commitments such as international human rights standards, and on social and economic policy objectives such as public health and meeting the sectoral need for migrant labour. It is an instance of the competing policy imperatives and contradictory pressures well recognised in the migration literature where pursuit of one policy objective is constrained by the need simultaneously to pursue other goals (Guiraudon 2006; Ruhs 2013: 33).

Negative impacts have to be mitigated by inclusive measures, as in a level of access to essential services provided by national law, so that, as Chauvin and Garcés-Mascareñas write in this volume (Chap. 3), formal exclusion is paradoxically coupled with formal inclusion beyond any informal inclusion by street bureaucrats (see also Chauvin and Garcés-Mascareñas 2012). The resulting, varying geography of national entitlements to healthcare and school education has been mapped across the EU28 (Spencer and Hughes 2015a) and in relation to a wider range of services in earlier work by the EU Fundamental Rights Agency (FRA 2011). Children have been the greatest beneficiary, their perceived lack of responsibility for their immigration status and their level of need ensuring that in many states they are granted more liberal access to essential services while still facing significant levels of exclusion (Spencer 2016a).

Notwithstanding that governments are themselves implementing these mitigating welfare measures, an analysis that they are the outcome of competing policy imperatives suggests that liberalisation of access to welfare services is in tension with, rather than contributing to, immigration control objectives. That tension is indeed evident in debates leading to national policy reforms, as between the UK Home Office and Department of Health in relation to access to HIV treatment, on which the rules were changed on public health grounds to allow access in 2012; and in the debates which led to law reform in Sweden to allow greater access to health care on the grounds, inter alia, that the voluntary clinics that had emerged to treat irregular migrants could not match Swedish standards of healthcare and administration (Social Affairs Department 2011; Spencer 2018). 


\subsection{Interpreting Inclusion at the Local Level}

Scholars have recently interpreted diverging local policies on irregular migrants as similarly reflecting competing policy objectives. Here the tension is played out between the national and sub-state tiers where there are shared policy competencies but the economic, political or cultural interests of the authorities diverge (Hepburn and Zapata-Barrero 2014; Spencer 2016b). Chauvin and Garcés-Mascareñas note in Chap. 3 that tension between national and local levels is particularly evident in relation to healthcare, with local authorities showing greater concern for public health than their national counterparts. In relation to provision of shelter by Dutch municipalities, Oomen \& Baumgärtel likewise pose local authorities as in conflict with national policy. Highlighting the municipalities' reliance on judgements of the European Committee of Social Rights as justification for provision of services, the authors frame municipal measures as the realisation of human rights for irregular migrants where those rights have been negated at the national level. A consequence of municipal actors' willingness to take on the role of duty bearer, they write, is that "local authorities invoke responsibilities derived from international human rights law to 'decouple' their policies from those adopted nationally" (2018: 614). Carrera and Parkin similarly see municipalities as active players in delivering human rights for irregular migrants in face of the exclusionary consequences of security-oriented national policies (2011: 17).

\subsubsection{The Local State}

It would be a mistake, however, to see local authorities as anything other than a part of the state, notwithstanding the semi-autonomous way in which they may appear to act. As a matter of international law, the state is a single entity regardless of its internal governance divisions, bound, for instance, by the state's international human rights obligations regardless of the degree of autonomy they may have (UNHRC 2015: 17).

Whereas the state is often perceived as responding to a pluralist collection of competing external and internal interests, in which the policies that emerge reflect the most powerful among them, Lahav argued in the context of immigration control that we should rather understand the state as 'neo-corporatist', managing different actors instrumentally, reconciling competing interests to achieve its own optimal outcomes (1998). She saw European states addressing the challenge of managing migration by devolving responsibility to a proliferation of new public and private actors (such as airline carriers and NGOs) in order to open up new opportunities for regulation, reinventing forms of state control.

Among those engaged to monitor and implement migration control functions is the local state. Far from representing a loss of control by the national state, incorporating local actors into the management of migration opens up new opportunities for 
control, enhancing its capacity and flexibility to manage migration while diminishing the political fallout at the national level for potentially unpopular measures (1998: 689). That trend, she argues, has led to some conflict between tiers and led to more diverse local outcomes that can give the semblance of policy incoherence. As Lahav later wrote with Guiraudon, reporting on a study of developments in Germany, France, and the Netherlands, national governments shift decision-making up to intergovernmental fora, down to local authorities, and out to non-state actors that, having different capacities and subject to fewer constraints, are more likely to achieve its policy goals:

This multifaceted devolution of migration policy has not resulted in states losing control over migration. Rather, it shows the adaptiveness of agencies within the central state apparatus in charge of migration control and their political allies. By sharing competence, states may have ceded exclusive autonomy yet they have done so to meet national policy goals, regaining sovereignty in another sense: capabilities to rule (Guiraudon and Lahav 2000:164).

Guiraudon and Lahav nevertheless found variation in local responses, from municipalities that followed the spirit of national policies to those resistant to it. A recent study of access to welfare support conditional on cooperation in the return procedure found that delegation of responsibility for implementation across tiers of government had weakened the impact of the policy tool. Moreover, shared responsibility across policy fields with differing views and interpretations of what is requiredwelfare agencies in particular perceiving their primary role as inclusion-was a further limiting factor (Rosenberger and Koppes 2018: 11).

We thus need not assume that the national state is always successful in controlling the role played by its sub-state tiers. Rather, we saw that there are varying degrees of autonomy accorded to them in states across Europe, and that there is strong evidence of de-coupling where there are open disagreements on the steps that sub-state tiers have taken. Lahav and Guiraudon's analysis does, however, raise the question whether some of the measures that local tiers are taking, while appearing to conflict with national immigration control objectives, are in fact contributing to their regulatory effect. Moreover, going beyond a focus on migration control, it raises the prospect that local actions, if not contributing to the regulation of migration, may nevertheless contribute to national social and economic policy objectives that are being pursued by other parts of the national state.

\subsubsection{Contributing to or Undermining National Policy Objectives?}

It is also helpful to recall that national policy measures that selectively grant access to services have been shown to serve the dual purpose of helping to manage the presence of migrants and increase rates of return. Morris highlights the way in which the stratification of labour and social rights attached to the ever-expanding range of immigration statuses has brought with it an element of control. The process 
of granting and delivery of rights provides a means of monitoring migrants' behaviour in order to assess eligibility, in turn requiring the sharing of information on them between public agencies, most notably by those involved in providing welfare support (2001: 388). Access to housing and social allowances for rejected asylum seekers are in some states made conditional on cooperation in the return procedure so that "Migration control is carried out with the help of conditional access to basic social rights. The tool combines a duty with a right, if a person cooperates with return processes, then he/she may be granted stay and welfare support" (Rosenberger and Koppes 2018: 2). Access to a temporary toleration status, such as Duldung in Germany, can bring with it a requirement to remain within a defined territorial area. In these cases, we can say that providing a level of access to welfare support is not in tension with immigration control objectives but is contributing to them.

In relation to shelter and support for irregular migrants in the Netherlands, Leerkes finds parallels with the historical social control function of poor relief. Just as poor relief served to mitigate the external effects of poverty such as threats to public health and public safety arising from the proximity of the poor to other residents, so the semi-inclusion of irregular migrants mitigates the effects of their exclusion and facilitates removal. In the Dutch case, poor relief for irregular migrants was initiated by civil society and municipalities and only later conjoined, under pressure, by the national government. While the latter nevertheless fears that inclusion may reduce migrants' incentive to cooperate with immigration control, Leerkes argues that this poor relief is nevertheless an element of it, facilitating locating potential deportees and thus their removal while also functioning to keep those who are not deportable off the streets and out of sight (2016: 148).

Provision of basic accommodation and subsistence operates alongside detention of those considered to pose an actual risk of anti-social behaviour. "Apparently", Leerkes argues, "providing accommodation and elementary allowances without full incapacitation is only considered a sufficient solution to control the perceived negative external effects of poverty among the 'docile' poor, that is, when there are only potential public health issues and minor types of nuisance". Allocation to accommodation or detention also depends on the extent to which individuals create a credible impression that they are prepared to 'work on return'. Those who do not are likely to find themselves excluded from the more inclusionary arrangements (Leerkes 2016: 147).

If nationally approved welfare measures are contributing to immigration control, we might equally expect to find that relationship where inclusive local measures are implementing national laws. In the UK, local authorities that have a statutory duty to support destitute migrant families excluded from mainstream welfare benefits are indeed required by law to pass on the details of the families to the national immigration service, thus facilitating resolution of their immigration status and, if no right to remain, their removal (Price and Spencer 2015: 23).

The question then is whether inclusive measures that municipalities adopt on their own initiative may also contribute to immigration control. The evidence suggests that this can be the case. Legal advice, for instance, attached to provision of shelter or independently, is regularly offered by municipalities in order to help 
irregular migrants resolve their immigration status, either by facilitating regularisation or voluntary return. The City of Utrecht claims a success rate of over $90 \%$ (some 900 people over ten years) for its 'problem-solving' approach to resolving immigration status; provision of shelter offering a means of access to the migrants and a sufficient basis for trust to provide advice and representation with the national authorities and, if status is not resolved, to facilitate voluntary return.

The City of Munich extends small grants to facilitate voluntary return, while Ghent provides advice on regularisation and return alongside information on other services, ensuring confidentiality so that individuals can seek advice without automatic referral to the immigration authorities. Shelter is provided in a reception centre to those who agree to cooperate in their return. Barcelona funds 55 non-profit 'social entities' to provide free legal support on how to obtain a regular status or renewal of expiring residence permits and to make representations on the migrants' behalf. The whole thrust of Barcelona's published strategy on irregular migrants is to promote regularisation and prevent lapsing into irregularity (Adjuntament de Barcelona 2017; CMISE 2019).

Municipalities do not frame their reasoning here as contributing to immigration control. Rather, it is to reduce the size of the irregular migrant population in the city and the challenge their exclusion presents. However, reducing irregularity through regularisation or voluntary return clearly contributes to control; as does the requirement adopted by some municipalities that provision of shelter is conditional on compliance with return procedures. The European Commission advocates increasing voluntary return as its first priority to improve the effectiveness of the EU return system. ${ }^{1}$ It is more cost-effective than supervised departures and the share of voluntary returns in the EU has increased from just 14\% of the total returns in 2009 to around $40 \%$ in 2013 (European Commission 2015b).

\subsection{Social and Economic Objectives}

Beyond measures related to resolving immigration status, municipalities cite economic and social policy reasons for inclusive service provision, ranging from crime prevention and public health to maintaining accurate population statistics, child protection, tackling homelessness, and maintaining the image of the city for tourism (Spencer and Delvino 2019). None of those objectives would conflict with national social policy objectives - only the target group to whom they are directed. Even in relation to irregular migrants many governments have not only permitted a level of access to education and health services, as we saw, but contribute directly to service provision: the Austrian government, for instance, co-funds with the City of Vienna

\footnotetext{
${ }^{1}$ European Commission Recommendation of 1.10 .2015 establishing a common "Return Handbook" to be used by Member States - Annex Return Handbook, C(2015)6250. https://ec. europa.eu/home-affairs/sites/homeaffairs/files/what-we-do/policies/european-agenda-migration/ proposal-implementation-package/docs/return_handbook_en.pdf
} 
the AmberMed clinic for irregular migrants in the city, while the Irish government funds Dublin's Women's Health Project, providing sexual healthcare services to migrants regardless of immigration status. The Italian government requires municipalities to provide outpatient care for irregular migrants; and Italian cities have been challenged by their government for failing to provide a service, as when Milan (in 2007) and later Bologna (in 2010) denied access to pre-school for children whose parents had no residence permit (Delvino and Spencer 2014: 19-21).

Beyond healthcare and education, the Spanish and French governments have made provision for victims of domestic violence to be able to seek help from the police without fear of deportation, and the Dutch government has extended this to victims of all crimes ('Free in, free out') — a decision taken after that approach was piloted in Amsterdam, an instance of a city initiative leading to national policy change. EU law (the Victims Directive of 2012) now explicitly requires that victims should receive confidential support regardless of residence status. Thus any municipalities that make provision for safe reporting are at least acting in line with the EU's legal requirements of its Member States.

The dependence of sectors of national labour markets on irregular migrants is well-documented in the literature, leading to some toleration of their status by national governments and the regular use of employment as a criteria for 'earned' regularisation. Different forms of employment, such as care work, are recognised in regularisation schemes according to their perceived value in the labour market (Chauvin et al. 2013). Hence municipalities such as those in industrial and agricultural regions of Italy that provide shelter and other amenities for irregular migrant labour and have assisted them with applications for regularisation during past amnesties (Delvino 2017: 7) are doing no more than is already evident from time to time in national practices. Ambrosini attributes the informal acceptance between local authorities, employers, and NGOs of the need to provide shelter and services to irregular seasonal workers as not only serving the needs of employers but also the avoidance of social conflict (2018: 19), a further objective shared by policymakers at the national and local levels.

\subsection{Explaining National Resistance}

The evidence thus suggests that municipal measures conflict less with national immigration, economic and social policy goals than might appear. If the challenge facing immigration control is to find the right balance between effective law enforcement and practical toleration policies that can deal with the ambiguities of modern society (as Engberson and Broeders argue, 2011: 185), we are perhaps seeing that balance emerging in the complementary strategies of the national and local state. Why then do national governments challenge inclusive local policies and deter other municipalities which have the potential to contribute but, as Genç argues, need the green light from their national governments to do so (2018: 11)? Four potential reasons emerge. Each requires further investigation. 
First, notwithstanding that the semi-inclusion of irregular migrants is to an extent authorised by national governments and that some municipal measures contribute towards national immigration and social policy objectives, there is a fear that these measures may act as an incentive to migrants to come or remain with irregular status. That concern has not been shown to be well-founded in the instances where it has been examined: in the enquiry that led to law reform in Sweden, for instance, where it was a prerequisite of the government that greater inclusivity should not result in an increase in irregularity (Social Affairs Department 2011). It was similarly refuted in relation to the extension of access to HIV treatment in the UK, where there was concern that it might incentivise 'health tourism' (NAT 2008). Nevertheless, the impact of inclusive measures on the behaviour of migrants with irregular status is a concern on which further empirical evidence is required.

Second, the fact that municipalities are challenged by national governments may reflect the primacy of immigration control objectives over social and employment policies, and of Interior Ministries over less powerful employment and social policy departments. The latter are able on occasion to trump the primacy of immigration control to secure inclusion of irregular migrants within welfare provision, not least into health care, but more often do not attempt to do so or succeed.

Third, the primacy which is here given to governmentality by municipalitiesthe need to regulate the local population in its entirety through inclusion (an argument well developed by Chauvin and Garcés-Mascareñas in Chap. 3) - may nevertheless for national governments be a lower priority than that of immigration control because of the high political salience of that issue at the national level. A significant irregular foreign population can be seen by policymakers and the public alike as not only an operational failure but a "challenge to state sovereignty, a proof of inadequate governance and an indicator of institutional crisis' that cannot be ignored" (Bommes and Sciortino 2011: 12).

Finally, there is a further possibility that government challenge to municipalities is more symbolic than substantive; that, despite a lack of actual challenge by municipalities to the achievement of immigration control objectives, governments want to signal that they are taking action to thwart their inclusive intent. Slaven and Boswell (2018) identify three theoretical accounts in the literature of symbolic policymaking: manipulation, to mobilise public support through compelling narratives; compensation, to divert attention from the gap between public preferences for restriction and more liberal policies, in contrast to manipulation which draws attention to it; and adaptation, addressing the discrepancy between what is operationally feasible and political narratives. Their analysis of UK policymaking on irregular entry leads them to conclude that adaptation may be a more important driver of symbolic policymaking than past scholarship has recognised. Further evidence is needed on the rationale for challenging municipal practices in order to establish which of these drivers of symbolic policymaking may apply in this case. 


\subsection{Cities Seeking Recognition}

An analysis that inclusion at the local level can contribute to national policy objectives may not be unhelpful to cities in their claim for recognition of their frontline role. National governments continue to be the principal actors in relation to the management of migration. Local authorities are increasingly involved as they respond to the presence of migrants in their territory but have thus far been left out of the framing and negotiation of policy development. That exclusion has, the International Organisation on Migration argues, contributed to local policy divergence on irregular migrants, with 'sanctuary' cities in the US going as far as to refuse to cooperate with some federal requirements in law enforcement (IOM 2018: 230).

Those European municipalities willing to challenge national governments have not been shy in making clear their assessment that provision of a service is necessary. In that visibility, Barcelona has perhaps been most bold, publishing its 33-page budgeted action plan (Adjuntament de Barcelona 2017). A polarity has thus emerged between the minority of cities that feel able to discuss publicly the provision they are making and those that only feel able to make provision in a less visible way. There are signs, nevertheless, that cities are gaining confidence in seeking recognition at an international level of the challenges they face. The Mayoral Forum on Mobility, Migration and Development, for instance, declaring that opening municipal services to irregular migrants is a humanitarian priority and fundamental for social cohesion, has called on international organisations and national governments to give them greater support and for legislation to be "more realistic" in minimizing the generation of exclusion. ${ }^{2}$ Such calls have been heard, and the need for local authorities to foster a level of inclusion is now acknowledged at the international level. The UN Secretary General has argued that both national and sub-national authorities need to consider pragmatic and rights-based options for managing irregular migrants including facilitating access to health, education, housing and other services - an approach, he insists, that is grounded in sound public policy and fosters social inclusion and the rule of law. ${ }^{3}$ The subsequent UN Global Compact on Migration (2017) secured agreement that there should be access to basic services regardless of immigration status and that service providers' cooperation with immigration authorities should not exacerbate the vulnerabilities of irregular migrants by compromising their safe access to them. ${ }^{4}$

The role of municipalities in relation to the inclusion of irregular migrants is thus now firmly on the agenda at the international level. At the national level, recognition

\footnotetext{
${ }^{2}$ See: https://www.uclg.org/en/media/news/barcelona-declaration-highlights-important-role-localgovernments-international-migration

${ }^{3}$ UN Secretary General 'Making Migration Work for All'. 12 December 2017. Paras 39-41. http:// refugeesmigrants.un.org/sites/default/files/sg_report_en.pdf

${ }^{4}$ Global Compact for Safe, Orderly and Regular Migration. Final draft 11 July 2018. Para 31. https://refugeesmigrants.un.org/sites/default/files/180711_final_draft_0.pdf
} 
that municipal measures can contribute to national immigration control and to national economic and social policy objectives could provide a more conducive context for pursuit of those discussions than assumptions that inclusive municipal policies are necessarily undermining what national governments are trying to achieve.

\subsection{Conclusion}

In this chapter I have considered the implications of municipal responses to irregular migrants living in their area. I questioned whether, as the tensions in multi-level governance on this issue suggest, inclusive responses undermine national immigration control objectives or whether they may at least in part contribute to them and to wider national policy goals.

While municipalities across Europe have differing mandates and levels of autonomy, their fulfilment of their responsibilities can be affected by the exclusion that irregular migrants experience from lawful access to the labour market, welfare support and services. Some respond with provision of access to advice, services, and documentation, diverging from the spirit and in some cases the letter of national law. That in turn can lead to tensions between national and local tiers, a de-coupling in multi-level governance that has contributed to analyses that diverging local responses conflict with the intentions of national governments to deter and exclude irregular migrants through welfare restrictions.

National and municipal responses can only be understood within a broader understanding of the nature of irregular migration as a structural phenomenon in advanced industrial societies, limiting the efficacy of enforcement measures that are designed to deter, detect and remove. The consequence is the continuing presence of irregular migrant residents with which municipalities, and less directly national governments, have to contend. Each find it necessary to address the negative consequences of welfare restrictions, through modest exceptions to national restrictions and through municipal service provision: competing policy imperatives ensuring that formal exclusion is simultaneously accompanied by a level of formal inclusion, particularly at the local level. In relation to municipalities the tensions that have arisen between national and local tiers have tended to suggest that inclusive measures run counter, rather than contribute, to immigration control. Yet Guiraudon and Lahav's analysis of the state's evolving capacity to use non-state and local state actors to manage migration, shifting the institutional locations of policymaking to achieve its own outcomes, raises the question whether this is in fact what we are witnessing in municipal activism on irregular migrants: not a loss of national control to the local state but a reinvention of it at the local level.

National welfare measures have already been shown by scholars to contribute in some respects to migration control, helping to monitor the location of irregular migrants and to regulate their behaviour in relation to compliance with return procedures. The question was then whether inclusive municipal measures that are taken 
outwith and in apparent contradiction of national policy may also make that contribution. The evidence cited shows that they may indeed do so, facilitating the regularisation of immigration status, voluntary return and compliance with national return procedures. Beyond immigration control objectives we saw that municipal policymakers cite a range of economic and social policy objectives as justification for the services they provide, none of which would conflict with national policy goals, only the target group to whom they are directed.

I concluded by asking why, in that case, national governments regularly challenge inclusive local policies and suggested four possible reasons: that there is a fear that, notwithstanding their contribution to national policy aims, municipal measures may encourage irregular migrants to come or to remain; the primacy of immigration control objectives over labour market and social policies, and of Interior Ministries over less powerful employment and social policy departments; that the primacy given to governmentality by municipalities - the need to monitor and regulate the local population in its entirety-is for national governments a lower priority than immigration control because of the political salience of that issue for the electorate; and finally that government challenge to municipalities is more symbolic than substantive-national governments want to be seen to be giving primacy to immigration control while less publicly acknowledging the need for a level of inclusion.

This analysis as ever raises more questions to be answered. Is there any justification for the fear that migrants with irregular status are attracted by the minimal level of welfare provision available to them in those localities where municipalities are inclusive, or that they are more likely to resist return? To what extent does provision of legal advice and representation, and assistance in voluntary return, contribute to migration management and control objectives? Are the instances where national governments challenge municipal policies merely symbolic or substantive attempts to change their approach?

A more fundamental question will then remain to be answered. If national and local tiers were to agree on the need to deliver a level of services to people whose immigration status is irregular, the question arises how far they should go. If these individuals are not to enjoy the same level of access to welfare services as other migrants or indeed citizens, what level of inclusion is appropriate, and on what grounds should that decision be made? As the legal scholar Linda Bosniak asked in her seminal text, The Citizen and the Alien (2006): when is it legitimate to restrict the rights of individuals as part of immigration control and when should the equality principle prevail (Pobjoy and Spencer 2012)?

In the answer to that question the proportionality principle will be key: a need to take account not only of the rights of irregular migrants (itself a grey area, as O'Cinneide argues in Chap. 4) but also of the impact of inclusive measures on a legitimate policy aim, migration control..$^{5}$ Thus, understanding the impact of

\footnotetext{
${ }^{5}$ The Global Compact on Migration (Para 31) indeed makes this point, signatories committed to ensuring in relation to service provision: "that any differential treatment must be based on law, proportionate, pursue a legitimate aim, in accordance with international human rights law." https:// refugeesmigrants.un.org/sites/default/files/180711_final_draft_0.pdf
} 
municipal measures on national policy objectives will be fundamental to resolving what the extent of irregular migrants' access to services should be.

\section{References}

Adjuntament de Barcelona. 2017. Government measure for encouraging access to regularisation and preventing lapsed regularity (Mesura de govern per afavorir l'accés a la regularitat i prevenir la irregularitat sobrevinguda). http://www.ben.cat/novaciutadania/pdf/mgrregularitat.pdf

Ambrosini, M. (2018). Irregular immigration in Southern Europe: Actors, dynamics and governance. Cham: Palgrave Macmillan.

Andersson, R. (2016). Europe's failed 'fight' against irregular migration: Ethnographic notes on a counterproductive industry. Journal of Ethnic and Migration Studies, 42(7), 1055-1075.

Bommes, M., \& Geddes, A. (Eds.). (2000). Immigration and welfare: Challenging the borders of the welfare state. London: Routledge.

Bommes, M., \& Sciortino, G. (2011). Irregular migration as a structural phenomenon (Chapter 1). In M. Bommes \& G. Sciortino (Eds.), Foggy social structures: Irregular migration, European labour markets and the welfare state. Amsterdam: Amsterdam University Press.

Bosniak, L. (2006). The citizen and the alien: Dilemmas of contemporary membership. Princeton: Princeton University Press.

Burchianti, F. (2016). Local governance, horizontal coordination and unauthorized immigrants' status in France and Spain (GRITIM Working Paper Series No 28). Barcelona: Universitat Pompeu Fabra.

Caponio, T. (2014). The legal and political dimension of local integration policy - KING project social science unit. Milano: Fondazione ISMU. http://king.ismu.org/wpcontent/uploads/ Caponio_DeskResearch.pdf.

Caponio, T., \& Borkert, M. (Eds.). (2010). The local dimensions of migration policy making. Amsterdam: Amsterdam University Press.

Carrera, S., \& Parkin, J. (2011). Protecting and delivering fundamental rights of irregular migrants at local and regional levels in the European Union. Brussels: European Union. https://doi. org/10.2863/61309.

CEMR. (2011). Local and regional government in Europe: Structures and competencies. Brussels: Council of European Municipalities and Regions.

Chauvin, S., \& Garcés-Mascareñas, B. (2012). Beyond informal citizenship: The moral economy of migrant illegality. International Political Sociology, 6(3), 241-259. https://doi. org/10.1111/j.1749-5687.2012.00162.x.

Chauvin, S., \& Garcés-Mascareñas, B. (2014). Becoming less illegal: Deservingness frames and undocumented migrant incorporation. Sociology Compass, 8(4), 422-432.

Chauvin, S., Garcés-Mascareñas, B., \& Kraler, A. (2013). Working for legality: Employment and migrant regularization in Europe. International Migration, 51(6), 118-131. https://doi. org/10.1111/imig.12109.

Clandestino. (2009). Size and development of irregular migration to the EU. Counting the uncountable: Data and trends across Europe. http://irregularmigration.net/filead$\mathrm{min} /$ irregular-migration/dateien/4.Background_Information/4.2.Policy_Briefs_EN/ ComparativePolicyBrief_SizeOfIrregularMigration_Clandestino_Nov09_2.pdf

CMISE. (2019). Migrants with irregular status in Europe: Guidance for municipalities. Oxford: City Initiative on Migrants with Irregular Status in Europe/Centre on Migration, Policy and Society (COMPAS). https://www.compas.ox.ac.uk/2019/migrantswith-irregular-status-in-europe-guidance-for-municipalities/ 
De Graauw, E., \& Vermeulen, F. (2016). Cities and the politics of immigrant integration: A comparison of Berlin, Amsterdam, New York City and San Francisco. Journal of Ethnic and Migration Studies, 42(6), 989-1012. https://doi.org/10.1080/1369183X.2015.1126089.

Delvino, N. (2017). European cities and migrants with irregular status: Municipal initiatives on the inclusion of irregular migrants in the provision of services. http://www.compas.ox.ac. uk/2017/european-cities-and-migrants-with-irregular-status/

Delvino, N., \& Spencer, S. (2014). Irregular migrants in Italy: Law and policy on entitlements to services. http://www.compas.ox.ac.uk/media/PR-2014-Irregular_Migrants_Italy.pdf

EMN. (2016). The return of rejected asylum seekers: Challenges and good practices. Brussels: European Migration Network.

Engberson, G., \& Broeders, D. (2011). Immigration control and strategies of irregular migrants: From light to thick fog (Chapter 8). In M. Bommes \& G. Sciortino (Eds.), Foggy social structures: Irregular migration, European labour markets and the welfare state. Amsterdam: Amsterdam University Press.

European Commission. (2010). Report from the commission to the European Parliament and the council: First annual report on immigration and asylum (Vol. 2009). Brussels: European Commission.

European Commission. (2015a). Self-rule index for local authorities (Release 1.0). http://ec.europa.eu/regional_policy/en/information/publications/studies/2015/ self-rule-index-for-local-authorities-release-1-0

European Commission. (2015b). Communication from the Commission to the European Parliament and to the Council - EU action plan on return, COM (2015) 453 final.

European Commission. (2017). Communication from the commission to the European Parliament and the council on a more effective return policy in the European Union - A renewed action plan, $\operatorname{COM}(2017) 200$ final.

FRA. (2011). Fundamental rights of migrants in an irregular situation in the European Union. Vienna: EU Fundamental Rights Agency.

Gebhardt, D. (2010). Irregular migration and the role of local and regional authorities. In S. Carrera \& M. Merlino (Eds.), Assessing EU policy on irregular immigration under the Stockholm Programme. Brussels: Centre for European Policy Studies (CEPS).

Genç, H. D. (2018). Responding to irregular migration: High potential of local governments in Turkey. International Migration, 56, 73-87. https://doi.org/10.1111/imig.12424.

GLA Economics. (2009). Economic impact on the London and UK economy of an earned regularisation of irregular migrants to the UK. London: Greater London Authority. https://www. london.gov.uk/sites/default/files/gla_migrate_files_destination/irregular-migrants-report.pdf

Guiraudon, V. (2006). Enlisting third parties in border control: A comparative study of its causes and consequences. In M. Caparini \& O. Marenin (Eds.). Borders and security governance: Managing borders in a globalised world. Geneva: Centre for the Democratic Control of Armed Forces; LIT Verlag.

Guiraudon, V., \& Lahav, G. (2000). A reappraisal of the state sovereignty debate: The case of migration control. Comparative Political Studies, 33(2), 163-195. https://doi.org/10.1177/00 10414000033002001.

Hepburn, E., \& Zapata-Barrero, R. (2014). Immigration policies in multilevel states (Chapter 1). In E. Hepburn \& R. Zapata Barrero (Eds.), The Politics of Immigration in Multi-level States: Governance and Political Parties. Basingstoke: Palgrave MacMillan.

Hollifield, J., Martin, P., \& Orrenius, P. (Eds.). (2014). Controlling migration: A global Perpective (3rd ed.). Stanford: Stanford University Press.

IOM. (2018). World migration report 2018. Geneva: International Organisation for Migration.

Koser, K. (2010). Dimensions and dynamics of irregular migration. Population, Space and Place, 16, 181-193. https://doi.org/10.1002/psp.587.

Lahav, G. (1998). Immigration and the state: The devolution and privatisation of immigration control in the EU. Journal of Ethnic and Migration Studies, 24(4), 675-694. https://doi.org/10 $.1080 / 1369183 X .1998 .9976660$. 
Laubenthal, B. (2011). The negotiation of irregular migrants' right to education in Germany: A challenge to the nation state. Ethnic and Racial Studies, 34(8), 1357-1373.

Leerkes, A. (2016). Back to the poorhouse? Social protection and social control of unauthorised immigrants in the shadow of the welfare state. Journal of European Social Policy, 26(2), $140-154$.

Morris, L. (2001). Stratified rights and the management of migration. National distinctiveness in Europe. Journal of European Societies, 3(4), 387-411. https://doi. org/10.1080/14616690120112190.

NAT. (2008). The myth of HIV health tourism. London: National Aids Trust. https://www.nat.org. uk/sites/default/files/publications/Oc-2008-The-Myth-of-HIV-Health-Tourism.pdf.

Oomen, B., \& Baumgärtel, M. G. N. (2018). Frontier cities - the rise of local authorities as an opportunity for international human rights law. European Journal of International Law, 29(2), 607-630.

Penninx, R., Blom, S., Caponio, T., Garcés-Mascareñas, B., Protasiewic, P. M., \& Schwarz, H. (2014). European cities and their migrant integration policies - case-studies from eight cities (KING project - Overview paper n.6/October 2014). Milano: Fondazione ISMU.

Pobjoy, J., \& Spencer, S. (2012). Equality for all? The relationship between immigration status and the allocation of rights in the United Kingdom. European Human Rights Law Review, 2, $160-175$.

Price, J., \& Spencer, S. (2015). Safeguarding children from destitution: Local authority responses to families with 'no recourse to public funds. Oxford: COMPAS report.

Rosenberger, S., \& Koppes, S. (2018). Claiming control: Cooperation with return as a condition for social benefits in Austria and the Netherlands. Comparative Migration Studies, 6(1), 26. https://doi.org/10.1186/s40878-018-0085-3.

Ruhs, M. (2013). The price of rights: Regulating international migration. Princeton: Princeton University Press.

Scholten, P. (2013). Agenda dynamics and the multi-level governance of intractable policy controversies: The case of migrant integration policies in the Netherlands. Policy Sciences, 46, 217-236.

Scholten, P., \& Penninx, R. (2016). The multi-level governance of migration and integration. In B. Garcés-Mascareñas \& R. Penninx (Eds.), Integration processes and policies in Europe: Contexts, levels and actors (pp. 91-108). Heidelberg/New York: Springer.

Schön, D., \& Rein, M. (1994). Frame reflection: Towards the resolution of intractable policy controversies. New York: Basic Books.

Slaven, M., \& Boswell, C. (2018). Why symbolise control? Irregular migration to the UK and symbolic policy-making in the 1960s. Journal of Ethnic and Migration Studies, 45, 1477-1495. https://doi.org/10.1080/1369183X.2018.1459522.

Social Affairs Department. (2011). Vård efter behov och på lika villkor - en mänsklig rättighet. In English summary: 31-46. Stockholm: Social Affairs Department, Swedish Government. http:// www.regeringen.se/rattsdokument/statens-offentliga-utredningar/2011/05/sou-201148/.

Spencer, S. (2016a). Postcode lottery for Europe's undocumented children: Unravelling an uneven geography of entitlements in the European Union. The American Behavioral Scientist, 60(13), 1613-1628. https://doi.org/10.1177/0002764216664945.

Spencer, S. (2016b). Managing irregular migrants within the EU. In S. Carrera \& E. Guild (Eds.), Irregular migration, trafficking and smuggling of human beings: Policy dilemmas in the EU. Brussels: CEPS. https://www.files.ethz.ch/isn/196442/Irregular\%20Migration,\%20 Trafficking\%20and\%20SmugglingwithCovers.pdf.

Spencer, S. (2018). Multi-level governance of an intractable policy problem: Migrants with irregular status in Europe. Journal of Ethnic and Migration Studies, 44(12), 2034-2052. https://doi. org/10.1080/1369183X.2017.1341708.

Spencer, S., \& Delvino, N. (2019). Municipal activism on irregular migrants: The framing of inclusive approaches at the local level. Journal of Immigrant \& Refugee Studies, 17, 27-43. https:// www.tandfonline.com/doi/full/10.1080/15562948.2018.1519867. 
Spencer, S., \& Hughes, V. (2015a). Outside and in: Legal entitlements to health care and education for migrants with irregular status in Europe. Oxford: COMPAS. www.compas.ox.ac.uk/media/ PR-2015-Outside_In_Mapping.pdf

Spencer, S., \& Hughes, V. (2015b). Fundamental rights for irregular migrants: Legal entitlements to healthcare and school education across the EU28. European Human Rights Law Review, 6, 604-616.

UNHRC. (2015). Role of local government in the promotion and protection of human rights (Final report of the Human Rights Council Advisory Committee. A/HRC/30/49).

Van der Leun, J. (2006). Excluding illegal migrants in the Netherlands: Between national policies and local implementation. West European Politics, 29, 310-326.

Varsanyi, M. (2011). Neoliberalism and nativism: Local anti-immigrant policy activism and an emerging politics of scale. International Journal of Urban and Regional Research, 35(2): 295311. https://doi.org/10.1111/j.1468-2427.2010.00958.x

Wilmes, M. (2011). Irregular migration and foggy organisational structures: Implications of a German city study (Chapter 6). In M. Bommes \& G. Sciortino (Eds.), Foggy social structures: Irregular migration, European labour markets and the welfare state. Amsterdam: Amsterdam University Press.

Open Access This chapter is licensed under the terms of the Creative Commons Attribution 4.0 International License (http://creativecommons.org/licenses/by/4.0/), which permits use, sharing, adaptation, distribution and reproduction in any medium or format, as long as you give appropriate credit to the original author(s) and the source, provide a link to the Creative Commons license and indicate if changes were made.

The images or other third party material in this chapter are included in the chapter's Creative Commons license, unless indicated otherwise in a credit line to the material. If material is not included in the chapter's Creative Commons license and your intended use is not permitted by statutory regulation or exceeds the permitted use, you will need to obtain permission directly from the copyright holder.

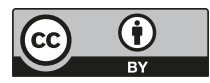

